\title{
The Field of Teacher Identity: Challenges, Endeavors, and Implications for English as a Foreign Language (EFL) Research
}

\author{
Bing Li \\ Southwest University \\ Zheng Li \\ Southwest University
}

Teacher identity provides a critical analytical lens for the field of English as a Foreign Language (EFL) research in the last decade. However, the complicatedness of identity leaves room for disputes over conceptualizations and components of EFL teacher identity, while at the same allowing for multiple theoretical approaches. This paper reviewed three major challenges facing the EFL teacher identity research field: conceptualization, components, and analytical approaches. Two recent endeavours were synthesized that have stood out among research attempts in this field: a situated learning perspective and a developmental lens. Implications are suggested for EFL research in the future.

Keywords: teacher identity, review, English as a foreign language

\section{INTRODUCTION}

In the literature on English as a foreign language (EFL) teachers, teacher identity as an analytical research lens has been widely adopted over the last decade for researchers and educators to understand how EFL teachers make sense of who they are and where they stand in the teaching profession (e.g., Mora et al., 2016; e.g., Moussu \& Llurda, 2008; Yuan, 2019). However, although the value of research on EFL teacher identity has been well documented in the literature (e.g., Vetter et al., 2016; Zhang, 2017), disputes are still arising over varying issues such as how teacher identity should be termed, interpreted, conceptualized, and (re)constructed by what factors (e.g., Beauchamp \& Thomas, 2009; Beijaard et al., 2004; Day \& Gu, 2009; Garner \& Kaplan, 2019). To date, research on EFL teacher identity has mainly followed the routes of teacher identity work on teachers from varying backgrounds and disciplines in terms of theoretical underpinnings, frameworks, methodologies and so on (Yuan, 2019). In this connection, understanding the challenges and endeavours emerging from the field of teacher identity in general might provide an approach to addressing the aforementioned disputes concerning EFL teacher identity.

As a matter of fact, the research field of teacher identity "has been growing without adequately addressing differences and similarities among diverse approaches, discerning strengths and weaknesses, and evaluating effectiveness, applicability, and the value of various frameworks" (Schutz, Francis, et al., 2018, p. 4). Against this background and in response to the need of a more nuanced understanding of EFL teacher identity, purpose of this paper is threefold. Firstly, this paper seeks to profile the major challenges facing the research field of EFL teacher identity. Secondly, this paper aims to map the endeavors that have 
stood out of works on EFL teacher identity in two directions (i.e., a situated learning perspective and the trend of capturing the developing nature of teacher identity). Thirdly, based upon the synthesis of challenges and endeavors, this paper intends to provide theoretical and practical suggestions for research on EFL teacher identity in the future.

\section{IDENTITY AND TEACHER IDENTITY}

Looking backward to the relationship between identity and teacher identity might be a good starting point to understand the predicaments challenging the field of the teacher identity. The construct of identity, used interchangeably with self or role sometimes, is time-honored. Written record of discussion on identity can be traced back to Plato (circa 428-347 B.C.) and Aristotle (circa 384-322 B.C.) in the western context, and to Tao Te Ching (circa 500 B.C.) in the eastern context (Gregg et al., 2011; Leary \& Tangney, 2003). It is anything but easy to define identity, however. Mead (1934), for example, took identity as a social construct composed of the "me" and the "I" that arise from social communication. Erikson (1968) emphasized the stages of identity formation in social contexts, pointing out that identity is "a sense of invigorating sameness and continuity" (p. 19). Tajfel (1974) drew on social identity theory, contending that identity is attached to social categorizations (e.g., occupation, party, class, race, and nationality). From a cognitive psychological perspective, Trafimow, Triandis, and Goto (1991) viewed identity as "private, collective, and public aspects of the self" (p. 649). Berzonsky (1999) held a social-cognitive perspective, conceiving identity as comprising three processing styles (i.e., informational, normative, and diffuseavoidant). Differently, Gee (2000) synthesized identity into four aspects, namely, nature-identity, institution-identity, discourse-identity, and affinity-identity.

From whichever perspective, however, identity is commonly taken as a product of negotiations with environments in a dynamic way. Attempts to define and approach identity have led to four major claims (Vignoles et al., 2011), that is, (1) identity negotiates private, interpersonal, and collective discourses (e.g., Berzonsky, 2008; Sedikides et al., 2011); (2) identity is fluid rather than static, fluctuating upon contextual shifts in life span (e.g., Brewer, 1999; Wetherell, 2010); (3) identity formation is a self-discovery process building on knowledge from previous stages (e.g., Berzonsky \& Neimeyer, 1994; Crocetti et al., 2008); and (4) identity should be approached through an integrative methodology, depending on problems addressed, resources available, and individual leanings (e.g., Kroger \& Marcia, 2011; Marcia, 2007).

Similarly, echoing the four features of identity, four core characteristics of teacher identity have surfaced among varied arguments (e.g., Beijaard et al., 2004; Hong et al., 2018; Pillen et al., 2013; Sutherland \& Markauskaite, 2012). First, teacher identity is multifaceted, comprising multiple "I's" or subidentities. The second concerns teachers' agency (i.e., self-directedness or active participation) in the construction of teacher identity when collaborating with the schools. Third, teacher identity is the interplay of personal dispositions and contextual influences. Fourth, teacher identity is an ongoing process of (re)constructions.

\section{MAJOR CHALLENGES}

\section{How Should EFL Teacher Identity Be Conceptualized?}

Beauchamp and Thomas (2009) argued that the hurdle of landing a definition should be crossed prior to an understanding of teacher identity. The current literature, as a matter of fact, is fraught with interpretations that are varying and sometimes overlapping (Zembylas \& Chubbuck, 2018). For example, from a personal knowledge perspective, Kelchtermans (1993) equated teacher identity with professional self which was referred to as "the way the teacher retrospectively reconstructs his or her career experiences as a story" (p. 444). Cooper and Olson (1996) asserted that teacher identity arises from teachers' personal knowledge about pupils and their own constructions of knowledge. Metaphorically, Maclure (1993) and Maguire (2008) pictured teacher identity as a continuing site of struggle and reworking. Standing at a sociocultural point, Olsen (2008) viewed teacher identity as a "methodological lens", a "pedagogical tool", and a "research frame" to attend to the "holistic, dynamic, and situated" (p. 5) nature of teacher development. 
Mayer (1999) posited that teacher identity and teacher role are two distinct constructs, the former referring to "investment", "commitment", and "what one feels" as a teacher, while the latter speaking to "function" or "what one should do" (p. 8) as a teacher. Clarke (2009) envisaged the construction of teacher identity as a way to "exercise professional agency" and to "maximize their potential" (p. 187).

Most existing research on EFL teacher identity follows the conventional conceptualizations of identity from various aspects (e.g., Lee, 2013; Trent, 2012) or does not bother to define teacher identity (e.g., Chan \& Clarke, 2014; Xu, 2013). For example, Trent (2012) borrowed from Danielewicz (2001) in defining EFL teacher identity as "our understanding of who we are [as EFL teachers]" (p. 10). Lee (2013) referred to identity as "who a person is and how s/he differs from others based on the qualities s/he possesses" (p. 331). Namaghi (2009) adopted Bakhtin's (Bakhtin, 1981) interpretation taking teacher identity as a dialogic sense of appealing for and exercising multiple voices, roles, and discourses. Loh and $\mathrm{Hu}$ (2014) provided no definition of EFL teacher identity at all in their publication reporting the lived experience of a novice EFL teacher in her first two years of teaching. So did Mora, Trejo, and Roux (2016) and Chang (2018) in their research comparing local Mexican EFL teachers and returned teachers from the USA, and exploring novice EFL teachers' identity development from the teaching practicum to the real teaching practice, respectively.

Some of these abovementioned interpretations have received criticisms. For example, Hornberger (2004) pointed out that the personal knowledge perspective concentrates so much on self-reflexivity that it will lead to subjectivity or self-doubt. The pedagogical or professionalism approach has been criticized as overly emphasizing instrumental goals (e.g., knowledge transmission and desirable academic attainments), so that "the complexity of education and its socializing mechanisms remain unexplored" (Dillabough, 1999, p. 378). Similarly, Britzman (1994) insisted that viewing teacher identity as a product of pedagogical skills would lead to "separation of teacher thinking from teacher identity" (p. 63).

Over one decade ago, Beijaard, Meijer, and Verloop (2004) carried out a comprehensive review of the relevant research from 1988 to 2000 and found that definitions of teacher identity in many studies were either implicit or absent at all. The situation is not getting better even now. In Olsen's (2011) words, a "nuanced and complex discussion" (p. 259) of teacher identity is still missing. Back to the EFL setting, in Yuan's (2019) most recent critical review of 22 existing studies on EFL teacher identity, there was no definition specifically given to language or EFL teacher identity; rather, a broad definition of teacher identity in general was borrowed from Day's (2011) conceptualization. This echoes Chan and Lo's (2017) claim that "Although there is growing literature examining language teacher identity formation in recent years, there is still no clear conceptualization of teacher identity" (p. 717).

\section{What Is EFL Teacher Identity Composed of?}

From different perspectives, researchers have argued for diverged constituents of teacher identity (Schutz, Francis, et al., 2018). For example, Kelchtermans (1993) examined teacher identity from five aspects: "self-image", "self-esteem", "job motivation", "task perception", and "future perspective". Day and Kington (2008) highlighted the importance of emotion in linking teachers' act and the embedded social structures. They hence suggested that teacher identity is a composite of three identities: the professional, the situated, and the personal. Centering around the term of teacher professional identity, Canrinus and colleagues (2011) viewed teachers' job satisfaction, self-efficacy, occupational commitment and change in the level of motivation as dominant indicators. Hong, Greene, and Lowery (2016) examined three-paired contrasting dimensions of identity construction (i.e., multiplicity vs. unity; social vs. individual; discontinuity vs. continuity). Berger et al. (2019) selected four groups of constituents including, for example, motivation to become a teacher, self-efficacy beliefs, sense of responsibility, affective commitment, and perception of expertise.

Most recently, Hong, Francis, and Schutz (2018) noted a core component-teacher agency-recurring across a collection of research on teacher identity from various theoretical perspectives. This is also in alignment with findings from previous studies where teacher agency was taken as central to teachers' professional development (e.g., Day \& Kington, 2008; Moore, 2008; Sexton, 2008; Vähäsantanen, 2015). The identification of agency implies that teachers' own capabilities of designing and pursuing their goals should receive due research attention. Another key constituent of teacher identity, as identified by Hong et 
al. (2018), is emotion. This finding echoes the contention of bringing together teachers' personal identities and professional identities (Day \& Gu, 2010).

On the contrary, largely because research on EFL teacher identity generally adopts small-scale and indepth qualitative approaches (Mora et al., 2016), it is of little interest for EFL researchers to break down teacher identity into smaller constituents; rather, they rely more heavily on theoretical frameworks to understand and analyze EFL teacher identity (Yuan \& Burns, 2017). Some researchers, however, make attempts although not expressly. For example, in Namaghi's (2009) study, EFL teacher identity consisted of "rationalized identity", "receiver of information", "information transmitter", and "implementer". Trent (2012) analyzed EFL teacher identity from the four aspects of practice, discourse, agency, and language.

\section{How Should EFL Teacher Identity Be Approached?}

Methodologically, most existing studies on teacher identity have been repeatedly identified to be either theoretical or qualitative (e.g., Hanna et al., 2019; Izadinia, 2013). It is the same in the case of research on EFL teacher identity. Yuan (2019) conducted a critical review of studies (2008-2017) on nonnative English teacher identity in L2 school context and found that all the 22 studies reviewed were small-scale and qualitative single- or multiple-case design. Most of these studies employed semi-structured interviews only (e.g., Chan \& Clarke, 2014; Chan \& Lo, 2017; Choe, 2016; Namaghi, 2009; Trent, 2012, 2014). Some studies involved both semi-structured interviews and other qualitative approaches like classroom research reports (Schaefer, 2013), field observation (Xu, 2013; Yuan \& Burns, 2017), email exchanges (Chang, 2018; Loh \& Hu, 2014), relevant documents (e.g., transcripts and internship plans or reports)(Chang, 2018; Mora et al., 2016), and reflective journals or autobiographies (Güngör, 2017; Xu, 2013). Following this line of qualitative paradigm, further noted by Yuan (2019), qualitative content analysis was employed as the most dominant data analysis approach (e.g., Chan \& Lo, 2017; Güngör, 2017; Mora et al., 2016; Namaghi, 2009; Trent, 2012; Yuan \& Burns, 2017), whilst approaches like discourse analysis (Chan \& Clarke, 2014; Trent, 2016, 2017) and narrative inquiry (Loh \& Hu, 2014) were also adopted.

In contrast to the proliferation of qualitative studies, research adopting the quantitative research paradigm on EFL teacher identity is quite rare. One such study was conducted by Wang (2015) where 108 high school EFL teachers in Mainland China were surveyed using Canrinus et al.'s (2011) four-indicator conceptual framework of teacher identity. Another study was implemented by Alaee (2015) who investigated the relationship between teacher identity and multiple intelligence among 137 Iranian EFL teachers.

Reasons are various for this "biased" dominance of the qualitative paradigm in EFL teacher identity research. One possible reason might be that: researchers generally contend that a qualitative approach can yield naturally emerging linguistic sense/meaning-making teachers assign to their lived experiences, thus leading to an in-depth understanding of EFL teacher identity in specific contexts (Taylor \& Bodgan, 1998; Yuan, 2019), whilst quantitative methods are unproductive and cannot capture the narrative and complicated characteristics of teacher identity (Hanna et al., 2019; Kelchtermans, 2009). However, such dominantly single paradigmatic (i.e., qualitative) view, as Shulman (1986) criticized, may lead to "potential corruption (or worse, trivialization)" in "any field of social science or educational research" (p. 4). Another pitfall of the qualitative paradigm lies in the plethora of theoretical frameworks that "have much in common" with "also many differences" (Willis, 2007, p. 147). For example, the 22 studies reviewed by Yuan (2019) were based on varying frameworks like identity as discourse, practice, and activity (Lee, 2013), the dual process of identity formation (Tsui, 2007a), community of practice (Yuan \& Burns, 2017), the framework of practice, language, and discourse (Trent, 2017), and the onion model (Güngör, 2017). Although nuanced understanding of EFL teacher identity might be achieved from diverse perspectives, relatively more generalizable knowledge is still needed that can be attained from studies primarily following the quantitative approach or combining the quantitative and qualitative paradigms. 


\section{RECENT ENDEAVORS}

\section{A Situated Learning Perspective}

Teaching identity learning is teacher learning or learning to teach (Beijaard, 2019; Schutz, Hong, et al., 2018). Learning to teach echoes the core of the situated learning theory, where learning is an ongoing social process, embedded necessarily in certain communities of practitioners where learners (particularly newcomers) endeavor to attain their full membership through situated activities such as apprenticeship, workshops, and sports games (Lave \& Wenger, 1991). The theory of situated learning provides an appropriate and cogent perspective that has growingly centered on two tenets: community of practice $(\mathrm{CoP})$ and legitimate peripheral participation.

A community of practice (CoP) is a "set of relations among persons, activity, and world, over time and in relation with other tangential and overlapping communities of practice" (Lave \& Wenger, 1991, p. 98). Two CoPs for teachers have received the most attention (Tsui et al., 2009): the university (where prospective teachers are prepared for the teaching profession) and the school (where in-service teachers practice teaching). For example, Tsui (2007) explored an EFL teacher' identity formation and negotiation with the school CoP, concluding that "the lived experiences of reifying oneself and having oneself reified as a member of a community constitute an important aspect of identification" (p. 678). Sarani and Najjar (2015) examined two emerging CoPs in an Iranian school: one with three EFL teachers, and the other, two Arabic teachers. The researchers found that the two CoPs could each serve as a major source for identity formation. Chang (2018) examined how Two Taiwanese EFL teachers negotiated their identities when caught in differentiated institutional structures of the teacher training CoP and the school CoP.

Legitimate peripheral participation (LPP) is a process where "[through] the mastery of knowledge and skill...newcomers...move toward full participation in the sociocultural practices of a community" (Lave \& Wenger, 1991, p. 29). In other words, newcomers at the outset are granted legitimate access to peripheral and low-stake activities in a CoP, which are nonetheless necessary and would over time lead to full participation in the same CoP. With regard to teacher education, research on LPP has mainly focused on prospective teachers and novice teachers. For example, in Tsui's (2007) study, the EFL teachers recalled his early career teaching experience highlighted that he played a minimal role in deciding on his own teaching even though he was granted legitimate access to practice. Kwan, Lopez-Real, and Tsui (2009) conducted a longitudinal study in Hong Kong involving three first-year EFL teachers. Likewise, He (2013) observed three EFL student teachers during their school-based part of the teacher training program in Mainland China.

Existing studies on CoP and LPP have converged on two major findings. The first major finding is that the process of LPP is often plagued with tensions of various kinds, such as longing to get the full participation of the school and obeying specific instructions from their mentors (e.g., Chang, 2018; Lave \& Wenger, 1991; Street, 2004; Timoštšuk \& Ugaste, 2010; Varghese et al., 2005). The second is that, the source of emerging tensions might be the conflicts between individual-difference-based needs and contextspecific demands (e.g., Han \& Wu, 2015; Street, 2004; Wenger, 2000; Yuan \& Burns, 2017).

\section{Mapping the Developing Nature}

Much research has shown that EFL teacher identity is dynamic, unstable, and shifting within certain contexts (e.g., Chan \& Lo, 2017; Chang, 2018; Kanno \& Stuart, 2011; Lee, 2013; Yuan, 2019). However, researchers standing from different perspectives have mapped inconsistent and sometimes contradicting developing trajectories of EFL teacher identity. For example, Kanno and Stuart (2011) conducted a study on two TESOL teachers in the USA throughout the 2004-2005 academic year of teaching. Upon graduation, these participants were trying to play the role of teachers rather than internalizing their teacher identity. One year later, however, they came to take themselves as real teachers, showing improved internal locus of control, in choosing focal points of teaching, and strengthened expertise in instructions. Trent (2012) observed that within one year seven beginning EFL teachers in Hong Kong developed from "being positioned by others", "positioning contested", to "becoming a teacher educator", breaking marginalization and acquiring competence and agency. In Lee's (2013) one-year study, four EFL writing teachers in Hong 
Kong were found to have been more empowered and committed to teaching writing after a training course, showing a positive trend of changing from a language teacher to a real writing teacher. Similarly, Yuan and Burns (2017) followed up two EFL teachers in Mainland China for one year and noted four distinctive routes of identity change: from "fisherman" to "fishing coach", from "craftsman" to "teacher educator", from "lonely fighter" to "collaborator", and from "housekeeper" to "change agent".

Converse to the trend toward strengthened EFL teacher identity, a declining tendency has also been identified in many other studies (e.g., Chan \& Clarke, 2014; Chang, 2018; Loh \& Hu, 2014; Trent, 2016). For example, in the case of Tsui's (2007b) study conducted in Mainland China, an EFL teacher recalled his first year of teaching as "a personal struggle" (p. 668) between "the boundary of being an authoritative teacher and a humble student" (p. 669). Such school-individual disparity was also confirmed in Farrell's (2006) single-case study, where a first-year EFL teacher reported doubt in the efficacy (representing teacher identity) of his own (learner-centered) teaching approach, whereas it was the opposite (teacher-centered) teaching approach that was encouraged in the school. In a four-year longitudinal study of four EFL teachers from Mainland China, Xu (2013) noted that three of the four teachers' imagined identity fell apart soon after they took their teachership whilst adopting more rule-based or schema-based identities. Likewise, Chan's (2014) two-year study found that the identity construction of two EFL teachers in Hong Kong was a site of tension where they had to struggle to strike a balance between their own positionings with those prescribed by the context.

\section{IMPLICATIONS FOR EFL RESEARCH}

Based on the brief look above at the literature on EFL teacher identity, several implications can be raised for educators and researchers. Although a growing body of studies have looked into EFL teacher identity from multiple facets (e.g., personal, social, linguistic, and pedagogical parts)(Wolff \& De Costa, 2017), researchers either directly adopt the conceptualization of teacher identity in general or give no clear interpretation at all (Chan \& Lo, 2017). However, this approach to conceptualization has long been critiqued to "underestimate the fact that variations in operationalizations may yield incomparable research findings, which cannot be used for cumulative theory construction" (Middendorp, 1991, p. 236). In this sense, researchers of EFL teacher identity could endeavor to provide a common language for them to communicate with one another. Much work can also be done including the ones that attempt to put the diverse frameworks into more integrative models, thus bridging the seemingly dispersed works on EFL teacher identity on a common ground. Comprising core elements (e.g., emotions, agency, self-efficacy, and motivation)(Hanna et al., 2019), such models can stay open-ended with an "integrating" function to meet the development of theories (Middendorp, 1991).

The theory of situated learning (Lave \& Wenger, 1991), among others, might prove to be a potential "encompassing" framework for EFL research (Tsui, 2011). Specifically, the theory of CoP demonstrates an openness to almost all contextual factors influencing EFL teacher identity, subsuming, for example, "social and economic influences" and "institutional support"(Choe, 2016), "rigid teacher recruitment system" (Chang, 2018), "psychical conditions of schools" and "xxam-oriented culture" (Güngör, 2017), "professional training" and "context of work" (Tsui, 2007b), "social-identification" (Varghese et al., 2005), and other contextual variables identified in He's (2013) three-stage framework. In this line of thinking, contextual factors can and should be further grouped in a more refined manner. For example, when the CoP is at an institutional level where prospective teachers are being prepared for the teaching profession, factors such as "program instructors and other participants' characteristics" (da Ponte \& Chapman, 2008) and "teaching context" (Beijaard et al., 2000) should be taken into account. When the CoP is at the state level, factors such as "educational policies" (He, 2013; Zeichner \& Gore, 1990) and "social identifications" (Varghese et al., 2005) should be given attention. Moreover, there is a bulk of empirical evidence supporting the wide and robust applicability of the situated learning perspective in EFL teacher identity research. Take the critical review work by Yuan (2019) as an example, 19 out of the 22 studies reviewed (e.g., Chan \& Lo, 2017; Mora et al., 2016; Trent, 2017; Trent et al., 2014; Yuan \& Burns, 2017) either took the discourse of EFL teaching as a community accomplishment (i.e., CoP) or highlighted the pursuit of legitimacy of 
participation in teaching (i.e., LPP). Tsui (2011) even noted that the situated learning perspective might be by far "perhaps the most powerful" (p. 33) framework for EFL teacher identity work.

One major mission of EFL teacher identity research is to help language teachers develop malleable and resilient identities; however, such mission cannot be fulfilled unless there is ongoing inquiry into the developing nature of teacher identity (Yuan, 2019). Trent (2012) also argued that longitudinal studies should be encouraged to explore the identity trajectory of EFL teachers "in different educational settings over an extended period of time as they cross multiple boundaries to take up different identity positions" (p. 274). In this connection, linking teacher training communities and school teaching communities through a dynamic lens might be a natural and fruitful attempt for researchers on EFL teacher identity, given the primacy attached to the university-based teacher training and the school-based teaching practice as two major CoPs for identity development (Tsui et al., 2009). By so doing, the developing identity trajectories of EFL teachers (novice teachers in particular) in crossing boundaries between the two important CoPs can be well documented for researchers and educators to enrich their knowledge of EFL teachers' identity conflicts, negotiations, survival, or thrival in this process. None the less, research following the longitudinal thread is still scant despite recent efforts (Chan \& Clarke, 2014; Chang, 2018; Loh \& Hu, 2014; Trent, 2016).

Refined portrayal of identity construction in single or multiple-case studies cannot suffice to map a comprehensive picture of EFL teacher identity. However, along and parallel with the qualitative research paradigm, there should be more attempts to capture a relatively more wholistic trend of EFL teacher identity development via quantitatively-driven or mixed-method approaches (Yuan, 2019). One possible attempt is for researchers to administer highly structured questionnaires among a large sample of EFL teachers. Another possibility is to conduct interventions in critical periods of time, for example, when EFL teachers are crossing boundaries between learner community and teacher community, or between teacher community and non-teacher community (Trent, 2016).

\section{CONCLUSION}

Researchers look into EFL teacher identity through miscellaneous lenses based on equally divergent theoretical underpinnings. Among seemingly "chaotic" endeavors, the situated learning perspective stands out thanks to its comparatively incorporating and open-ended nature, while a second standout trend in this field is the growingly increased interest in grasping the trajectories of EFL teacher identity. However, on the one hand, researchers following the situated learning perspective should beware of its critical limitations, such as its "focus on how individual identity develops within the structure of group practice rather than considering other ways" (Varghese et al., 2005, p. 30) and "weak consideration of power relations and underlying ideologies within groups" (p. 31). On the other hand, the dynamic of EFL teacher identity over time is still understudied in comparison to the bulk of literature from a cross-sectional perspective.

\section{ACKNOWLEDGEMENT}

This work was supported by MOE (Ministry of Education in China) Project of Humanities and Social Sciences (Grant Number: 17YJC880047) and Chongqing Municipal Education Commission Project for Graduate Education Reform (Grant Number: yjg203028). 


\section{REFERENCES}

Alaee, M. (2015). Investigating the relationship between multiple intelligences and professional identity of Iranian EFL teachers. Journal of Pan-Pacific Association of Applied Linguistics, 19, 1-21.

Bakhtin, M. (1981). The dialogic imagination: Four essays by M. M. Bahktin. (M. Holquist Ed., C. Emerson \& M. Holquist Trans.). Austin: University of Texas Press.

Beauchamp, C., \& Thomas, L. (2009). Understanding teacher identity: An overview of issues in the literature and implications for teacher education. Cambridge Journal of Education, 39(2), 175189.

Beijaard, D. (2019). Teacher learning as identity learning: Models, practices, and topics. Teachers and Teaching: Theory and Practice, 25(1), 1-6.

Beijaard, D., Meijer, P.C., \& Verloop, N. (2004). Reconsidering research on teachers' professional identity. Teaching and Teacher Education, 20(2), 107-128.

Beijaard, D., Verloop, N., \& Vermunt, J.D. (2000). Teachers' perceptions of professional identity: An exploratory study from a personal knowledge perspective. Teaching and Teacher Education, 16(7), 749-764.

Berger, J-L., \& Lê Van, K. (2019). Teacher professional identity as multidimensional: Mapping its components and examining their associations with general pedagogical beliefs. Educational Studies, 45(2), 163-181.

Berzonsky, M.D. (1999). Identity styles and hypothesis-testing strategies [Article]. Journal of Social Psychology, 139(6), 784-789.

Berzonsky, M.D. (2008). Identity formation: The role of identity processing style and congnitive processes. Personality and Individual Differences, 44, 645-655.

Berzonsky, M.D., \& Neimeyer, G.J. (1994). Ego identity status and identity processing orientation: The moderating role of commitment. Journal of Research in Personality, 28(4), 425-435.

Brewer, M.B. (1999). Multiple identities and identity transition: Impliactions for Hong Kong. Int. J. Intercultural Rel., 12(1), 187-197.

Britzman, D.P. (1994). Is there a problem with knowing thyself? Toward a poststructuralist view of teacher identity. In T. Shanahan (Ed.), Teachers thinking, teachers knowing: Reflections on literacy and language education (pp. 53-75). National Council of Teachers of English.

Canrinus, E.T., Helms-Lorenz, M., Beijaard, D., Buitink, J., \& Hofman, A. (2011). Profiling teachers' sense of professional identity. Educational Studies, 37(5), 593-608.

Chan, C., \& Clarke, M. (2014). The politics of collaboration: Discourse, identities, and power in a schooluniversity partnership in Hong Kong. Asia Pacific Journal of Teacher Education, 42(3), 291-304.

Chan, C., \& Lo, M. (2017). Exploring inclusive pedagogical practices in Hong Kong primary EFL classrooms. International Journal of Inclusive Education, 21(7), 714-729.

Chang, Y-J. (2018). Certified but not qualified? EFL pre-service teachers in liminality. Journal of Language Identity \& Education, 17(6), 48-62.

Choe, H. (2016). Identity formation of Filipino ESL teachers teaching Korean students in the Philippines: How negative and positive identities shape ELT in the outer circle. English Today, 32(1), 5-11.

Clarke, M. (2009). The ethico-politics of teacher identity. Educational Philosophy and Theory, 41(2), $185-200$.

Cooper, K., \& Olson, M.R. (1996). The multiple 'I's' of teacher identity. In M. Kompf, W.R. Bond, D. Dworet, \& R.T. Boak (Eds.), Changing Research and Practice: Teachers' Professionalism, Identities and Knowledge (pp. 78-89). Palmer Press.

Crocetti, E., Rubini, M., \& Meeus, W. (2008). Capturing the dynamics of identity formation in various ethnic groups: Development and validation of a three-dimensional model. Journal of Adolescence, 31(2), 207-222.

da Ponte, J.P., \& Chapman, O. (2008). Preservice mathematics teachers' knowledge and development. In L.D. English (Ed.), Handbook of international rearch in mathematics education (2nd ed., pp. 223-261). Routledge. 
Danielewicz, J. (2001). Teaching selves. Identity, pedagogy, and teacher education. State University of New York Press.

Day, C. (2011). Uncertain Professional Identities: Managing the Emotional Contexts of Teaching. In C. Day \& J.C-K. Lee (Eds.), New Understandings of Teacher's Work: Emotions and Educational Change (pp. 45-64). Springer.

Day, C., \& Gu, Q. (2009). Veteran teachers: Commitment, resilience and quality retention. Teachers and Teaching: Theory and Practice, 15(4), 441-457.

Day, C., \& Gu, Q. (2010). The new lives of teachers (1st ed.). Routledge.

Day, C., \& Kington, A. (2008). Identity, well-being and effectiveness: The emotional contexts of teaching. Pedagogy, Culture \& Society, 16(1), 7-23.

Dillabough, J-A. (1999). Gender politics and conceptions of the modern teacher: Women, identity and professionalism. British Journal of Sociology of Education, 20(3), 373-394.

Erikson, E.H. (1968). Identity: Youth and crisis. Norton.

Farrell, T.S. (2006). The first year of language teaching: Imposing order. System, 34(2), 211-221.

Garner, J.K., \& Kaplan, A. (2019). A complex dynamic systems perspective on teacher learning and identity formation: An instrumental case. Teachers and Teaching: Theory and Practice, 25(1), $7-$ 33.

Gee, J.P. (2000). Identity as an analytic lens for research in education. Review of Research in Education, 25(1), 99-125.

Gregg, A.P., Sedikides, C., \& Gebauer, J.E. (2011). Dynamics of identity: Between self-enhancement and self-assessment. In S.J. Schwartz, K. Luyckx \& V.L. Vignoles (Eds.), Handbook of identity theory and research (pp. 305-327). Springer.

Güngör, F. (2017). The tensions between EFL teacher identities and INSET in the Turkish context. Profile: Issues in Teachers Professional Development, 19(1), 13-27.

Han, C., \& Wu, Z. (2015). Teacher learning across boundaries: A challenge to the legitimacy of language teachers' disciplinary knowledge. Asia-Pacific Journal of Teacher Education, 43(3), 225-242.

Hanna, F., Oostdam, R., Severiens, S.E., \& Zijlstra, B.J.H. (2019). Domains of teacher identity: A review of quantitative measurement instruments. Educational Research Review, 27, 15-27.

He, P. (2013). Learning to teach in school-university partnership: Tension, agency and identity [Unpublished Dissertation, The University of Hong Kong].

He, P., \& Lin, A.M.Y. (2013). Tensions in school-university partnership and EFL pre-service teacher identity formation: A case in mainland China. The Language Learning Journal, 41(2), 205-218.

Hong, J., Francis, D.C., \& Schutz, P.A. (2018). Research on teacher identity: Common themes, implications, and future directions. In P.A. Schutz, J. Hong, \& D.C. Francis (Eds.), Research on Teacher Identity: Mapping Challenges and Innovations (pp. 243-251). Springer.

Hong, J., Greene, B., \& Lowery, J. (2016). Multiple dimensions of teacher identity development from preservice to early years of teaching: A longitudinal study. Journal of Education for Teaching, pp. 115.

Hornberger, N.H. (2004). The continua of biliteracy and the bilingual educator: Educational linguistics in practice. In J. Brutt-Griffler \& M. Varghese (Eds.), Re-writing bilingualism and the bilingual educator's knowledge base (pp. 63-79). Multilingual Matters.

Izadinia, M. (2013). A review of research on student teachers' professional identity. British Educational Research Journal, 39(4), 694-713.

Kanno, Y., \& Stuart, C. (2011). Learning to become a second language teacher: Identities in practice. The Modern Language Journal, 95(2), 236-252.

Kelchtermans, G. (1993). Getting the story, understanding the lives: From career stories to teachers' professional development. Teaching and Teacher Education, 9(5/6), 443-456.

Kelchtermans, G. (2009). Who I am in how I teach is the message: Self-understanding, vulnerability and reflection. Teachers and Teaching: Theory and Practice, 15(2), 257-272. 
Kroger, J., \& Marcia, J.E. (2011). The identity statuses: Origins, meanings, and interpretations. In S.J. Schwartz, K. Luyckx, \& V.L. Vignoles (Eds.), Handbook of identity theory and research (pp. 3153). Springer.

Kwan, T., Lopez-Real, F., \& Tsui, A.B.M. (2009). Mentoring, learning and identity formation. In A.B.M. Tsui, G. Edwards, F. Lopez-Real, T. Kwan, D. Law, P. Stimpson, R. Tang, \& A. Wong (Eds.), Learning in school-university partnership: Sociocultural perspectives (pp. 69-89). Routledge.

Lave, J., \& Wenger, E. (1991). Situated learning: Legitimate peripheral participation. Cambridge University Press.

Leary, M.R., \& Tangney, J.P. (2003). The self as an organizing construct in the behavioral and social sciences. In M.R. Leary \& J.P. Tangney (Eds.), Handbook of self and identity (2nd ed., pp. 1-18). Guilford Press.

Lee, I. (2013). Becoming a writing teacher: Using "identity" as an analytic lens to understand EFL writing teachers' development. Journal of Second Language Writing, 22(3), 330-345.

Loh, J., \& Hu, G. (2014). Subdued by the system: Neoliberalism and the beginning teacher. Teaching and Teacher Education, 41, 13-21.

Maclure, M. (1993). Arguing for your self: Identity as an organising principle in teachers' jobs and lives. British Educational Research Journal, 19(4), 311-322.

Maguire, M. (2008). "End of term": Teacher identities in a post-work context. Pedagogy, Culture and Society, 16(1), 43-55.

Marcia, J.E. (2007). Theory and measure: The identity status interview. In M. Watzlawik \& A. Born (Eds.), Capturing identity: Quantitative and qualitative methods (pp. 1-14). University Press of America.

Mayer, R.E., Moreno, R., Boire, M., \& Vagge, S. (1999). Maximizing constructivist learning from multimedia communications by minimizing cognitive load. Journal of Educational Psychology, 91(4), 638-643.

Mead, G.H. (1934). Mind, self, and society: From the standpoint of a social behaviorist (Vol. 1). University of Chicago press.

Middendorp, C.P. (1991). On the conceptualization of theoretical constructs. Quality and Quantity, 25(3), 235-252.

Moore, F.M. (2008). Agency, identity, and social justice education: Preservice teachers' thoughts on becoming agents of change in urban elementary science classrooms. Research in Science Education, 38(5), 589-610.

Mora, A., Trejo, P., \& Roux, R. (2016). The complexities of being and becoming language teachers: Issues of identity and investment. Language and Intercultural Communication, 16(2), 182-198.

Moussu, L., \& Llurda, E. (2008). Non-native English-speaking English language teachers: History and research. Language Teaching, 41(3), 315-348.

Namaghi, S.A.O. (2009). A data-driven conceptualization of language teacher identity in the context of public high schools in Iran. Teacher Education Quarterly, 36(2), 111-124.

Olsen, B. (2008). Introducing teacher identity and this volume. Teacher Education Quarterly, 35(3), 3-6.

Olsen, B. (2011). "I am large, I contain multitudes": Teacher identity as a useful frame for research, practice, and diversity in teacher education. In A.F. Ball \& C.A. Tyson (Eds.), Studying diversity in teacher education (pp. 257-273). Rowman \& Littlefield Publishers.

Pillen, M., den Brok, P., \& Beijaard, D. (2013). Profiles and change in beginning teachers' professional identity tensions. Teaching and Teacher Education, 34(487), 86-97.

Sarani, A., \& Najjar, R. (2015). Formulation of language teachers' identity in the situated learning of language teaching community of practice. Iranian Journal of Applied Language Studies, 5(2), $167-192$.

Schaefer, L. (2013). Beginning teacher attrition: A question of identity making and identity shifting. Teachers and Teaching: Theory and Practice, pp. 1-15. 
Schutz, P.A., Francis, D.C., \& Hong, J. (2018). Research on teacher identity: Introduction to mapping challenges and innovations. In P.A. Schutz, J. Hong, \& D.C. Francis (Eds.), Research on Teacher Identity: Mapping Challenges and Innovations (pp. 3-12). Springer.

Schutz, P.A., Hong, J., \& Francis, D.C. (2018). Research on teacher identity: Mapping challenges and innovations. Springer.

Sedikides, C., Gaertner, L., \& O’Mara, E. (2011). Individual self, relational self, collective self: Hierarchical ordering of the tripartite self. Psychological Studies, 56(1), 98-107.

Sexton, D.M. (2008). Student teachers negotiating identity, role, and agency. Teacher Education Quarterly, 35(3), 73-88.

Shulman, L.S. (1986). Paradigms and research programs in the study of teaching: A contemporary perspective. In M.C. Wittrock (Ed.), Handbook of research on teaching. Macmillan.

Street, C. (2004). Examining learning to teach through a social lens: How mentors guide newcomers into a professional commuity of learners. Teacher Education Quarterly, 31(2), 7-24.

Sutherland, L., \& Markauskaite, L. (2012). Examining the role of authenticity in supporting the development of professional identity: An example from teacher education. Higher Education, 64(6), 747-766.

Tajfel, H. (1974). Social identity and intergroup behaviour. Social Science Information/Sur les Sciences Sociales, 13(2), 65-93.

Taylor, S., \& Bodgan, R. (1998). Introduction to Qualitative Research Methods: A Guidebook and Resource. John Wiley \& Sons, Inc.

Timoštšuk, I., \& Ugaste, A. (2010). Student teachers’ professional identity. Teaching and Teacher Education, 26(8), 1563-1570.

Trafimow, D., Triandis, H.C., \& Goto, S.G. (1991). Some tests of the distinction between the private self and the collective self. Journal of Personality and Social Psychology, 60(5), 649-655.

Trent, J. (2012). Becoming a teacher: The identity construction experiences of beginning English language teachers in Hong Kong. Australian Educational Researcher, 39(3), 363-383.

Trent, J. (2014). The professional development of teacher identities in Hong Kong: Can a short-term course make a difference. Professional Development in Education, 37(4), 613-632.

Trent, J. (2016). The identity construction experiences of early career english language teachers in hong kong. Great expectations and practical realities. Research Papers in Education, 31(3), 316-336.

Trent, J. (2017). Discourse, agency and teacher attrition: Exploring stories to leave by amongst former early career English language teachers in Hong Kong. Research Papers in Education, 32(1), 84 105.

Trent, J., Gao, X., \& Gu, M. (2014). Language teacher education in a multilingual context: Experiences from Hong Kong. Springer.

Tsui, A.B.M. (2007a). Complexities of identity formation: A narrative inquiry of an EFL teacher. Tesol Quarterly, 41(14), 657-680.

Tsui, A.B.M. (2007b). What shapes teachers' professional development. In J. Cummings \& C. Davison (Eds.), International handbook of English language teaching (pp. 1053-1066). Springer.

Tsui, A.B.M. (2011). Teacher education and teacher development. In E. Hinkel (Ed.), Handbook of research in second language teaching and learning (Vol. II, pp. 21-39). Routledge.

Tsui, A.B.M., Edwards, G., Lopez-Real, F., Kwan, T., Law, D., Stimpson, P., . . Wong, A. (Eds.). (2009). Learning in school-university partnership: Sociocultural perspectives. Routledge.

Vähäsantanen, K. (2015). Professional agency in the stream of change: Understanding educational change and teachers' professional identities. Teaching and Teacher Education, 47, 1-12.

Varghese, M., Morgan, B., Johnston, B., \& Johnson, K.A. (2005). Theorizing language teacher identity: Three perspectives and beyond. Journal of Language, Identity, and Education, 4(1), 21-44.

Vetter, A., Hartman, S.V., \& Reynolds, J.M. (2016). Confronting unsuccessful practices: Repositioning teacher identities in english education. Teaching Education, 27(3), 305-326. 
Vignoles, V.L., Schwartz, S.J., \& Luyckx, K. (2011). Introduction: Toward an integrative view of identity. In S.J. Schwartz, K. Luyckx, \& V.L. Vignoles (Eds.), Handbook of identity theory and research (pp. 1-27). Springer.

Wang, Y. (2015). Examining organizational citizenship behavior of Japanese employees: A multidimensional analysis of the relationship to organizational commitment. The International Journal of Human Resource Management, 26(4), 425-444.

Wenger, E. (2000). Communities of practice and social learning systems. Organization, 7(2), 225-246.

Wetherell, M. (2010). The field of identity studies. In M. Wetherell \& C.T. Mohanty (Eds.), The Sage handbook of identities (pp. 3-26). Sage.

Willis, J.W. (2007). Foundations of qualitative research: Interpretive and critical approaches. SAGE Publications, Inc.

Wolff, D., \& De Costa, P.I. (2017). Expanding the language teacher identity landscape: An investigation of the emotions and strategies of a NNEST. The Modern Language Journal, 101(S1), 76-90.

$\mathrm{Xu}, \mathrm{H}$. (2013). From the imagined to the practiced: A case study on novice EFL teachers' professional identity change in China. Teaching and Teacher Education, 31(1), 79-86.

Yuan, R. (2019). A critical review on nonnative English teacher identity research: From 2008 to 2017. Journal of Multilingual and Multicultural Development, 40(6), 518537.

Yuan, R., \& Burns, A. (2017). Teacher identity development through action research: A Chinese experience. Teachers and Teaching: Theory and Practice, 23(6), 729-749.

Zeichner, K.M., \& Gore, J. (1990). Teacher socialization. In W.R. Houston (Ed.), Handbook of Research on Teacher Education: A Project of the Association of Teacher Educators (pp. 329-348). Macmillan.

Zembylas, M., \& Chubbuck, S. (2018). Conceptualizing "teacher identity": A political approach. In P.A. Schutz, J. Hong, \& D.C. Francis (Eds.), Research on teacher identity: Mapping challenges and innovations. Springer.

Zhang, Y. (2017). I speak Chinese but I am teaching English: Exploring the influence of nonnative speakership in the construction of language teacher identity. Theory and Practice in Language Studies, 7(12), 1236-1242. 